\title{
Spatial and Temporal Dynamics of Botrytis Blight of Gladiolus (Gladiolus grandiflorus L.) Caused by Botrytis gladiolorum in Susceptible and Resistant Varieties
}

\section{Sehajpal PK*, Singh PJ and Hunjan MS}

Department of Floriculture and Landscaping, Punjab Agricultural University, Ludhiana-141004, India

\begin{abstract}
Botrytis blight caused by Botrytis gladiolorum is the most devastating disease under North Indian conditions. The development and spread of this disease is favoured by cool and moist weather conditions generally prevailing in the months of February and March under Punjab conditions. The spatial and temporal dynamics of any disease provide valuable information on development of disease epidemics. The current experiments were planned to measure spatial and temporal development of Botrytis blight in susceptible (Sancerre) and resistant varieties (Nova Lux and Jacksonville Gold) of gladiolus under natural field conditions. It was observed that there was an increase in spread of the disease with time in both the susceptible and resistant varieties. The spread of disease in the varieties Sancerre, Jacksonville Gold and Nova Lux, varied from -500 to $425,-375$ to 200 and -400 to $250 \mathrm{~cm}$ in East-West direction and -450 to $500,-125$ to 300 and -150 to $300 \mathrm{~cm}$ in North-South direction from the infection focus on $X$ and $Y$ axis, respectively, during 2011-12. The disease spread was more during 2012-13. The disease intensity and its lateral spread from the foci of infection were higher in the susceptible variety than the resistant. Agrometeorological data on wind direction revealed that the progression of disease was more towards the southeastern direction due to flowing of northwesterly winds during January-March, during both the crop seasons, i.e. 2011-12 and 2012-13.
\end{abstract}

Keywords: Gladiolus; Botrytis gladiolorum; Spatial and temporal distribution

\section{Introduction}

Gladiolus is an important ornamental plant valued for its beautiful flower spikes. It is widely used in flower arrangements, bouquet-making and indoor decorations. It is a bulbous crop and mainly propagated by corms and cormels. The commercial cultivation of this flower crop has picked up during the last three decades. Presently, it is being grown mainly for domestic purpose but holds potential for export market, too

Gladiolus is grown commercially on an area of 6,000 ha in India [1]. It is mainly cultivated in Karnataka, West Bengal, Maharashtra, Punjab, Haryana, Uttar Pradesh, Tamil Nadu, Jammu and Kashmir, Uttarakhand, Delhi, Sikkim and Himachal Pradesh. In Punjab state, area under this crop is 180.6 ha [2].

Diseases are one of the major constraints in the profitable cultivation of gladiolus. Gladiolus plants and corms are susceptible to various diseases. Among these, Botrytis gladiolorum Timm, is one of the major destructive diseases that causes significant economic loss to the growers. Besides producing small to large, oval to round brown spots on leaves, the pathogen also produces water-soaked spots on flower petals. Incipient floral infections cause flowers to rot during transit to market, reducing its market value [3]. The fungus also causes basal stem infections, which may penetrate to the corm. Corm rotting may continue in cold storage conditions, too. The sclerotia of the fungus sometimes appear on leaves, stalks and corms under wet field or storage conditions. Infected corms often develop soft rot during cold storage if moisture condensation occurs due to temperature fluctuations.

The disease spreads rapidly in February-March, when the plant canopy becomes dense and temperature is favorable. Under such environmental factors, there is abundant sporulation on diseased plant parts, particularly on leaves, stems and flowers. A drift of spores from a nearby planting may jeopardize the crop even if rigorous control measure is adopted for control of the disease through frequent fungicidal sprays. Spatial and temporal distribution provides useful information on the rate of spread of the disease and gives an assessment of potential crop loss [4]. Limited quantitative information is available on the spatial and temporal relationships that develop between airborne inoculum and disease intensity during the course of aerially spread epidemics in B. gladiolorum. Therefore, the present studies on spatial and temporal distribution of the disease were conducted to generate this valuable information in B. gladiolorum.

\section{Materials and Methods}

\section{Plant material}

Corms of the susceptible gladiolus variety Sancerre and resistant varieties Jacksonville Gold and Nova Lux were planted in $10 \mathrm{~m} \times 10 \mathrm{~m}$ plots in the field in the first week of November at experimental farm of the Department of Floriculture and Landscaping, Punjab Agricultural University, Ludhiana, during two consecutive seasons, i.e. 2011-12 and 2012-13. The row-to-row and plant-to-plant spacing was kept as $25 \mathrm{~cm}$ with a total of 1681 plants per plot in each of the varieties. Recommended package of practices were followed for crop cultivation [5].

${ }^{*}$ Corresponding author: Sehajpal PK, Department of Floriculture and Landscaping, Punjab Agricultural University, Ludhiana-141004, India, Tel: 0187 422 0825; E-mail: pksehajpal@pau.edu

Received July 07, 2015; Accepted July 29, 2015; Published August 01, 2015

Citation: Sehajpal PK, Singh PJ, Hunjan MS (2015) Spatial and Temporal Dynamics of Botrytis Blight of Gladiolus (Gladiolus grandiflorus L.) Caused by Botrytis gladiolorum in Susceptible and Resistant Varieties. J Plant Pathol Microb 6: 290. doi:10.4172/2157-7471.1000290

Copyright: @ 2015 Sehajpal PK, et al. This is an open-access article distributed under the terms of the Creative Commons Attribution License, which permits unrestricted use, distribution, and reproduction in any medium, provided the original author and source are credited. 
Citation: Sehajpal PK, Singh PJ, Hunjan MS (2015) Spatial and Temporal Dynamics of Botrytis Blight of Gladiolus (Gladiolus grandiflorus L.) Caused by Botrytis gladiolorum in Susceptible and Resistant Varieties. J Plant Pathol Microb 6: 290. doi:10.4172/2157-7471.1000290

Page 2 of 4

\section{Pathogen inoculation and disease epiphytotics}

An artificially infected $B$. gladiolorum plant was placed exactly in the center of the plot in each of the varieties in the end of January and left there till termination of the experiment. High moisture in the field was created by irrigating the field on the day of start of experiment and after two days, and subsequently normal irrigation schedule followed. The location of plants was taken as identity of the plants for recording of data.

\section{Disease measurement}

The disease dynamics was monitored by recording observations on incidence and severity of the disease at weekly intervals, up to a period of 6 weeks. Disease severity was recorded on 0-4 rating scale as followed by Sehajpal and Singh [6]. The data on spatial and temporal disease dynamics was analyzed using Sigma Plot Ver. 11

\section{Results and Discussion}

A graphic presentation of measurements on dynamics of botrytis blight in susceptible (Sancerre) and resistant varieties (Jacksonville Gold and Nova Lux) of gladiolus is presented in Figures 1 and 2. The data show that intensity and spread of the disease were highly influenced by the time period and direction of the wind. The disease started spreading from infection foci in all the varieties after one week of inoculation.

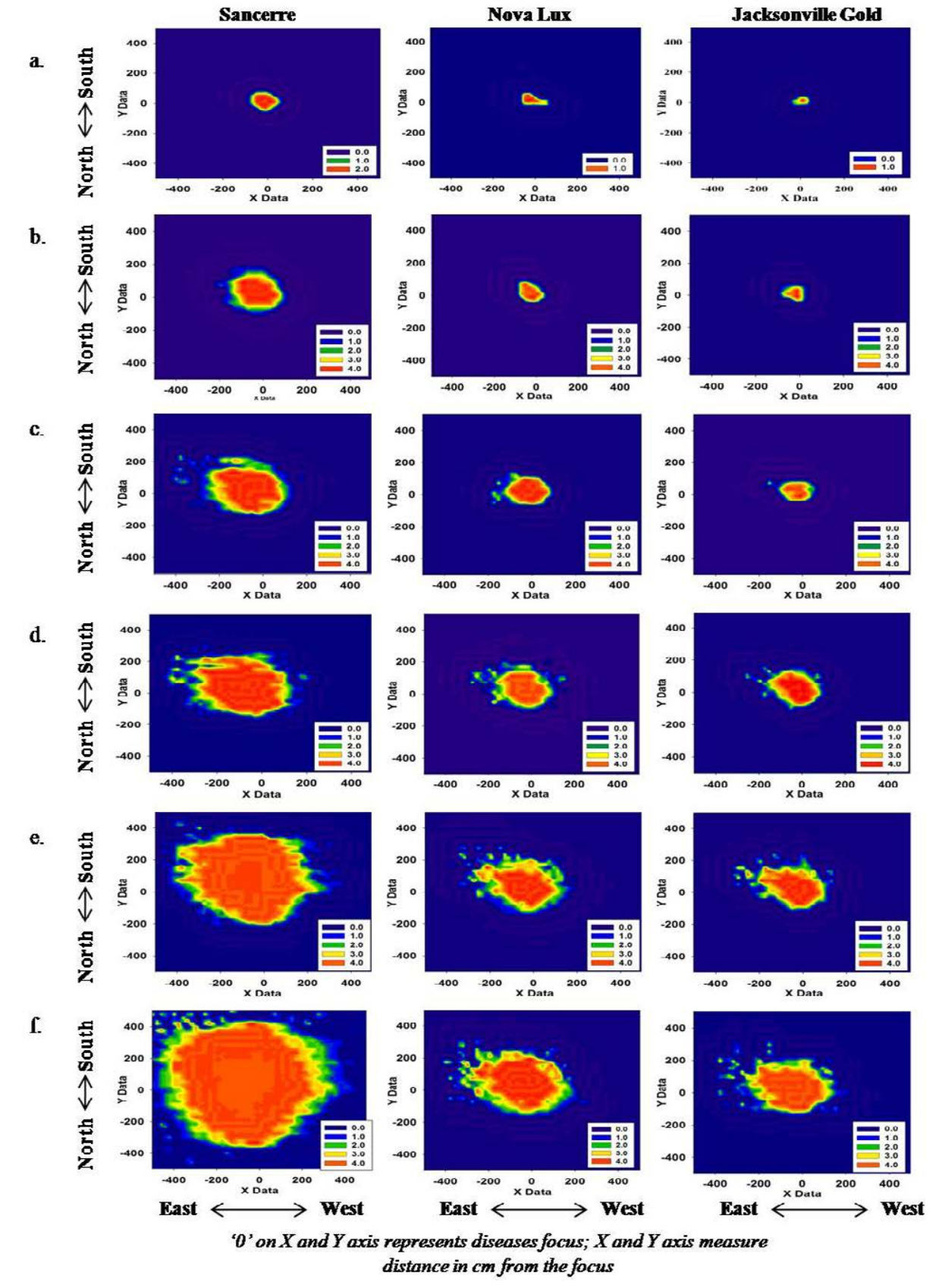

Figure 1: Spatial and temporal spread of Botrytis I blight of gladiolus in resistant and susceptible varieties during 2011-12 after (a) 1 week (b) 2 week (c) 3 week (d) 4 week (e) 5 week (f) 6 week of inoculation. 
Citation: Sehajpal PK, Singh PJ, Hunjan MS (2015) Spatial and Temporal Dynamics of Botrytis Blight of Gladiolus (Gladiolus grandiflorus L.) Caused by Botrytis gladiolorum in Susceptible and Resistant Varieties. J Plant Pathol Microb 6: 290. doi:10.4172/2157-7471.1000290

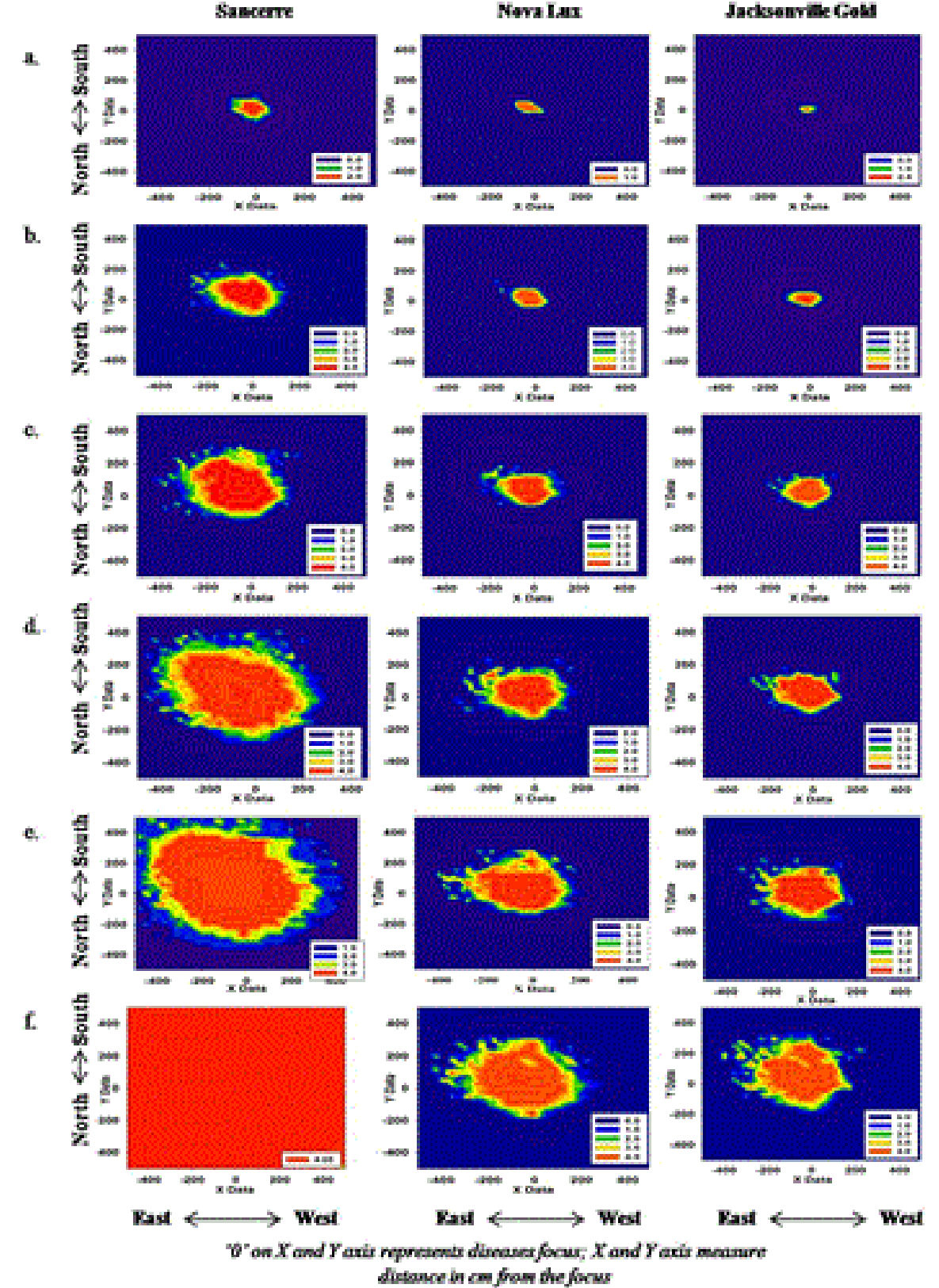

Figure 2: Spatial and temporal spread of Botrytis I blight of gladiolus in resistant and susceptible varieties during 2012-13 after (a) 1 week (b) 2 week (c) 3 week (d) 4 week (e) 5 week (f) 6 week of inoculation.

The spread of the disease was more in the susceptible variety Sancerre followed by resistant varieties Nova Lux and Jacksonville Gold.

The disease spread from the infection focus in variety Sancerre during the first year ranged from -75 to $50,-200$ to $100,-400$ to 175 , -425 to $200,-450$ to 350 and -500 to $425 \mathrm{~cm}$ in East-West direction (X-axis) and from -50 to $75,-100$ to $175,-125$ to $225,-150$ to $300,-200$ to 425 and -450 to $500 \mathrm{~cm}$ in North-South direction (Y-axis) over a period of six weeks. The disease spread in the second year ranged from -100 to $50,-225$ to $150,-425$ to $200,-425$ to 275 and -500 to $500 \mathrm{~cm}$ in East-West direction (X-axis) and from -75 to $100,-100$ to $225,-150$ to $300,-275$ to 400 and -500 to 500 in North-South direction (Y-axis) over a period of six weeks
Development and spread of the disease was highly restricted in the resistant varieties Jacksonville Gold and Nova Lux as compared to the susceptible variety Sancerre. The disease spread in the variety Jacksonville Gold ranged from -25 to $25,-75$ to $25,-175$ to $50,-250$ to $100,-300$ to 125 and -375 to $200 \mathrm{~cm}$ in East-West direction and 0 to $25,-25$ to $50,-25$ to $75,-75$ to $150,-100$ to 200 and -125 to $300 \mathrm{~cm}$ in North-South direction, respectively, in the first year, whereas, from -25 to $25,-100$ to $50,-200$ to $100,-275$ to $125,-325$ to 175 and -400 to 225 $\mathrm{cm}$ in East-West direction and 0 to $25,-50$ to $50,-75$ to $125,-100$ to $175,-125$ to 225 and -175 to $325 \mathrm{~cm}$ in North-South direction from the infected plant on $\mathrm{X}$ and $\mathrm{Y}$ axis in the second year. The disease spread in variety Nova Lux was -75 to $25,-75$ to $50,-175$ to $100,-250$ to $150,-375$ to 175 and -400 to $250 \mathrm{~cm}$ in East-West direction and 0 to $25,-25$ to 75 , 
-50 to $125,-100$ to $200,-125$ to 275 and -150 to $300 \mathrm{~cm}$ in North-South direction from the foci of infection on $\mathrm{X}$ and $\mathrm{Y}$ axes, respectively, over a period of six weeks in first year. The spatial distribution of the disease in the second year ranged from -75 to $25,-100$ to $50,-225$ to $150,-300$ to $175,-400$ to 200 , and -425 to $275 \mathrm{~cm}$ in East-West direction and 0 to $25,-25$ to $75,-50$ to $175,-125$ to $225,-150$ to 275 and -175 to $300 \mathrm{~cm}$ in North-South direction from the foci of infection on $\mathrm{X}$ and $\mathrm{Y}$ axes, respectively, over a period of six weeks. The results show that the spatial and temporal distribution of the disease was more or less similar in Jacksonville Gold and Nova Lux varieties of gladiolus.

In general, the disease progression was slow in early stages of infection but increased considerably with the increase in time interval. The spread of the disease progressively increased after third week in all three varieties. The freshly infected plants were found adjacent to the previously diseased ones and spread along the direction of the wind forming new foci of infection. It was observed that the spread of the disease in all the varieties was more towards the South Eastern direction due to blowing of North Westerly winds during the crop growth period. The wind may carry the air borne conidia to healthy uninfected plants producing secondary foci of infection. The pattern of distribution of the disease was similar in all the varieties in both the years of experimentation. Overall, disease severity was low in the first year as compared to the second year. This was probably due to less cumulative rainfall $(8.1 \mathrm{~mm})$ received during the January to March during the first year, i.e. 2011-12, in contrast to more of cumulative rainfall $(20.10 \mathrm{~mm})$ received in the corresponding months during the second year, i.e. 2012-13. Agrometeorological data show that there were no significant variations in the temperature and wind direction in both the years.

The study on spatial and temporal pattern of development of Botrytis in onion support our hypothesis that secondary spread of the disease is caused by airborne conidia produced on necrotic tissues $[7,8]$. In the present study, it was reported that disease severity was more near the infected plant as compared to the distant ones. This was supported by the findings of Johnson and Powelson [9] who analyzed spore dispersal in grey mold of snap beans and found that disease incidence was $70 \%$ at a distance of $0.9 \mathrm{~m}$ from the inoculum source but it was less than $25 \%$ at a distance of $4 \mathrm{~m}$. Further, it was observed that there was increase of disease intensity as well as spread of the infection with the increase in time intervals. The airborne inoculum of Botrytis leaf blight caused by Botrytis squamosa was analyzed over space and time by Carisse et al [10] who observed that lesion density varied from 0.00 to 15.8 and from 0.00 to 43.0 lesions per plant as airborne conidium concentration varied from 0.00 to 16.8 and from 0.00 to 56.7 conidia / $\mathrm{m}^{3}$ in 2004 and 2006, respectively.

The association of airborne conidia of $B$. cinerea with disease has been recorded in other crops, too, such as strawberry [11,12], raspberry [13], grapes [14,15] and gerbera [16]. Knowledge of temporal and spatial dynamics of plant diseases has led to the development of several forecasting systems, hence, resulted in better disease management [17].

On the whole, investigations on the spatial and temporal distribution of the disease show that fungicidal applications during onset of the disease would lead to better management as they keep the inoculum level low. Another management strategy for decision making is that the crop canopy should be properly covered with the fungicidal sprays keeping in view the direction of the wind.

\section{Conclusion}

The study showed that spatial distribution during early stages of the disease development was low but significant expansion of disease foci occurred during the fourth, fifth and sixth week. Furthermore, dissemination or secondary spread of the pathogen occurred from infected to healthy plants along the direction of the wind.

\section{Acknowledgments}

The authors are highly indebted to the ICAR for providing the necessary funds for carrying out this research work.

\section{References}

1. Sharma CK, Saxena M, Sharma V (2012) Influence of nutrition and planting density on the yield of gladiolus: Production of spikes, corms and cormels of gladiolus. Lap Lambert Academic Publishing, p. 112.

2. Singh R, Singh PJ, Singh K, Dhatt KK, Kumar G, et al. (2014) Status of Floriculture in Punjab. DFR Bull 10, Indian Council of Agricultural Research, New Delhi, pp. 1-35.

3. Magie RO (1956) Gladiolus Botrytis control. Proc Fla State Hort Soc 69: 337 43.

4. Balasubramaniam R (1995) Botrytis Control using a Disease Management System - 1994/95 Experience in five vineyards. Winepress 43: 6-8.

5. Kumar R, Sidhu GS (2011) Flower cultivation and Landscaping. Punjab Agricultural University. P. 72.

6. Sehajpal PK, Singh PJ (2014) Effect of temperature, leaf wetness period, light and darkness on development of Botrytis blight (Botrytis gladiolorum Timm.) of gladiolus (Gladiolus grandiflorum L.) Int J Res Appl Nat Soc Sci 2: 211-18.

7. Sutton JC, Swanton CJ, Gillespie TJ (1978) Relation of weather variables and host factors to incidence of airborne spores of Botrytis squamosa. Can J Bot 56: $2460-469$

8. Sutton JC, James TDW, Rowell PM (1983) Relation of weather and host factors to an epidemic of Botrytis leaf blight in onions. Can J Plant Pathol 5: 256-65.

9. Johnson KB, Powelson ML (1983) Analysis of spore dispersal gradient of Botrytis cinerea and grey mold disease gradient in snap beans. Phytopathology 73: $741-46$.

10. Carisse O, Savary S, Willocquet L (2008) Spatiotemporal relationships between disease development and airborne inoculum in unmanaged and managed Botrytis leaf blight epidemics. Phytopathology 98: 38-44.

11. Jarvis WR (1960) An apparatus for studying hygroscopic responses in fungal conidiophores. Trans Br Mycol Soc 45: 315-19.

12. Miller PM, Waggoner PE (1957) Dispersal of Botrytis cinerea among strawberries. Phytopathology 47: 24-25 (Abstr)

13. Jarvis WR (1962) The dispersal of spores of Botrytis cinerea Fr. In a raspberry plantation. Trans Br Mycol Soc 45: 549-59.

14. Corbaz R (1972) Investigations in fungal spores trapped in a vineyard. Phytopathology Z 74: 318-28.

15. Built J, Verdu D (1973) Annual variation in the aerial sporing of Botrytis cinerea in vineyard. Ann Phytopathol 5: 319

16. Kerssies A (1993) Horizontal and vertical distribution of airborne conidia of Botrytis cinerea in a Gerbera crop grown under glass. Neth J P1 Path 99: 30311.

17. Hughes G, McRoberts N, Burnett JJ (1999) Decision-making and diagnosis in disease management. Plant Pathol 48: 147-53. 